\title{
Pengaruh Model Pembelajaran Scramble Terhadap Kemampuan Pemahaman Konsep Matematis Siswa Pada Materi Pola Bilangan Kelas VIII
}

\author{
Siti Karlinawati ${ }^{1}$, Rosmaiyadi ${ }^{2}$, Citra Utami $^{3}$ \\ MI Al-Ikhlas Singkawang1, STKIP Singkawang ${ }^{1,2}$, Singkawang, Indonesia \\ ssiti6509@gmail.com ${ }^{1}$, rosmaiyadialong@gmail.com ${ }^{2}$, citrautami1990@gmail.com³
}

\begin{tabular}{ll}
\hline \hline Kata Kunci: & ABSTRAK \\
Scramble; Pemahaman Konsep & Penelitian ini bertujuan untuk: (1) mengetahui pengaruh \\
Matematis; Respon & penggunaan model pembelajaran scramble terhadap \\
& kemampuan pemahaman konsep matematis siswa; $(2)$ \\
& mengetahui respon siswa terhadap model pembelajaran \\
& scramble; (3) mengetahui keterlaksanaan pembelajaran \\
& terhadap model pembelajaran scramble. Penelitian ini \\
& dilaksanakan di SMP Negeri 5 Singkawang kelas VIII \\
& menggunakan metode ekperimen dengan rancangan berupa \\
posttest only control design. Sampel pada penelitian ini yaitu \\
kelas VIII C sebagai kelas eksperimen dan kelas VIII A sebagai \\
kelas kontrol. Instrumen pengumpulan data yang digunakan \\
adalah tes kemampuan pemahaman konsep matematis siswa, \\
angket respon siswa dan lembar observasi keterlaksanaan \\
pembelajaran. Teknik analisis data yang digunakan yaitu effect \\
size, rerata skor dan dengan persentase. Hasil penelitian \\
menunjukan bahwa: (1) Terdapat pengaruh penggunaan model \\
pembelajaran scramble terhadap kemampuan pemahaman \\
konsep matematis siswa pada materi pola bilangan kelas VIII \\
SMP Negeri 5 Singkawang dengan nilai Effect Size (ES) yaitu \\
1,75; (2) Respon siswa positif terhadap model pembelajaran \\
scramble pada materi pola bilangan dengan rata-rata skor \\
mencapai $76,52 \% ;$ (3) Penggunaan model pembelajaran \\
scramble pada materi pola bilangan terlaksana dengan \\
kriteria sangat baik yaitu mencapai persentase sebesar \\
86,O0\%.
\end{tabular}

\section{PENDAHULUAN}

Kemampuan pemahaman konsep yang baik dalam pembelajaran matematika mampu membantu siswa dalam memahami dan mengaplikasikannya dalam kehidupannya. Hal ini sesuai dengan pendapat Sanjaya (dalam Fitriyani, 2017:151), pemahaman konsep adalah kemampuan siswa yang berupa penguasaan sejumlah konsep yang dipelajari, tetapi mampu mengungkapkan kembali dalam bentuk lain yang mudah dimengerti. Selain itu, Kilpatrick (Utami dan Anitra, 2019:104), menyatakan bahwa pemahaman konsep (conceptual understanding) adalah kemampuan dalam memahami konsep, operasi dan relasi dalam matematika. Namun pada kenyataan yang terjadi, kemampuan pemahaman konsep matematis siswa SMP Negeri 5 Singkawang masih tergolong rendah. Hal tersebut dibuktikan dengan hasil wawancara dengan salah satu guru bidang studi mata pelajaran matematika kelas VIII SMP 
Negeri 5 Singkawang, dijelaskan bahwa siswa masih banyak keliru dalam memahami konsep materi pembelajaran terutama dalam mengerjakan soal-soal cerita. Kemampuan pemahaman konsep siswa tergolong rendah juga diperkuat oleh penelitian yang dilakukan oleh Isrotun (2014), bahwa pemahaman konsep matematika selama ini masih rendah. Hal ini ditunjukkan dengan kemampuan siswa menyatakan ulang sebuah konsep sebesar 30\%, kemampuan siswa membedakan contoh dan non contoh sebesar 17,5\%, kemampuan siswa memecahkan masalah yang berkenaan dengan konsep sebesar $17,5 \%$, kemampuan siswa mengklasifikasikan objek menurut sifat tertentu sebesar $20 \%$. Hal ini juga sejalan dengan penelitian yang dilakukan oleh Hadi (2015), bahwa kemampuan pemahaman siswa terhadap konsep-konsep matematika masih tergolong rendah, kurang dari 50 persen siswa belum memenuhi Kriteria Ketuntasan Minimal (KKM).

Selain dibuktikan dengan hasil wawancara, rendahnya kemampuan pemahaman konsep matematis siswa SMP Negeri 5 Singkawang juga dibuktikan dengan hasil prariset yang telah dilakukan yang terdiri dari indikator-indikator kemampuan pemahaman konsep matematis, yaitu: (1) menyatakan ulang suatu konsep; (2) mengklasifikasikan objek-objek menurut sifat-sifat tertentu sesuai dengan konsepnya; (3) menyajikan konsep dalam berbagai bentuk representasi matematika; dan (4) menggunakan, memanfaatkan, dan memilih prosedur atau operasi tertentu. Soal prariset diberikan kepada 26 orang siswa dan soal tersebut diberikan sebanyak 2 soal. Hasil dari soal prariset tersebut yaitu untuk nomor 1 hanya 4 orang siswa dengan persentase 15,3\% yang menjawab soal dengan benar, sedangkan terdapat 15 orang siswa dengan persentase sebesar $57,7 \%$ yang salah menjawab soal, dan terdapat 7 orang siswa dengn persentase $26,9 \%$ yang tidak menjawab soal. Sedangkan untuk soal nomor 2, hasil yang diperoleh hanya terdapat 6 orang siswa saja dengan persentase $23 \%$ yang benar dalam menjawab soal, sedangkan terdapat 17 orang siswa dengan persentase sebesar $65,3 \%$ yang salah dalam menjawab soal dan 3 orang siswa dengan persentase 11,5\% yang tidak menjawab soal. Selain dengan hasil prariset, respon siswa kelas VIII SMP Negeri 5 Singkawang terhadap pelajaran matematika juga masih terbilang rendah. Dalam kegiatan pembelajaran di kelas terlihat hanya 1-2 orang anak yang mau bertanya. Sebagian siswa hanya mencatat apa yang ditulis guru di papan tulis, ada yang hanya diam dan tampak kebingungan memperhatikan penjelasan guru. Ketika diberikan soal yang berbeda dari contoh, siswa kesulitan dalam menyelesaikannya soal tersebut sehingga banyak siswa yang mendapat nilai pada mata pelajaran matematika belum mencapai kriteria ketuntasan minimal (KKM) yaitu 70.

Satu di antara materi pelajaran matematika yang akan diteliti yaitu materi pola bilangan di kelas VIII, karena dalam materi ini masih banyak siswa yang mendapat nilai yang belum mencapai Kriteria Ketuntasan Minimal (KKM). Kelemahan pemahaman konsep dalam hal ini siswa belum bisa mengembangkan menyatakan ulang suatu konsep dengan tepat, serta keliru dalam memahami soal sehingga tidak bisa mengaplikasikan konsep atau algoritma dalam pemecahan masalah. Selain itu, ketika berdiskusi kelompok hanya siswa tertentu saja yang berpartisipasi lebih aktif, sementara siswa yang lain enggan berusaha untuk mengemukakan pendapatnya.

Untuk mengantisipasi masalah di atas, perlunya perubahan cara mengajar dan mengembangkan model pembelajaran. Oleh karena itu, peneliti mencoba menggunakan model pembelajaran satu di antaranya yaitu model pembelajaran scramble. Model pembelajaran scramble adalah model pembelajaran yang mengajak siswa untuk bekerja secara berkelompok untuk membagi ilmu yang dimiliki serta belajar secara individu. Model pembelajaran scramble mengajak siswa bermain sambil belajar, bersosialisasi, dan berkompetisi. Hasil penelitian Sari (2014) dan Rabeka (2018) bahwa hasil belajar siswa yang diajarkan menggunakan model pembelajaran scramble lebih tinggi dibandingkan dengan yang diajarkan menggunakan model pembelajaran konvensional. Siswa diharapkan mampu mencari jawaban dan cara penyelesaian dari soal. Berdasarkan latar belakang tersebut dapat disusun tujuan penelitian ini sebagai berikut: (1) Untuk mengetahui pengaruh penggunaan model pembelajaran scramble terhadap kemampuan pemahaman konsep matematis siswa pada materi pola bilangan; (2) Untuk mengetahui respon siswa terhadap model pembelajaran scramble pada materi pola bilangan; dan (3) Untuk mengetahui keterlaksanaan model pembelajaran scramble pada materi pola bilangan. 


\section{METODE}

Penelitian ini menggunakan True Experimental Design dengan pendekatan kuantitatif karena data yang diperoleh berhubungan dengan angka-angka yang dapat dihitung secara matematis (Sugiyono, 2015:112). Desain penelitian ini menggunakan dua kelas yaitu kelas eksperimen dengan menggunakan model pembelajaran scramble dan kelas kontrol dengan menggunakan model pembelajaran konvensional. Adapun desain yang digunakan adalah Posttest Only Control Design. Tempat penelitian dilaksanakan di SMP Negeri 5 Singkawang, dan waktu penelitian yang digunakan berlangsung selama tiga hari. Populasi dalam penelitian ini yaitu seluruh siswa kelas VIII SMP Negeri 5 Singkawang yang terdiri atas kelas VIII A, kelas VIII B, dan kelas VIII C. Teknik pengambilan sampel penelitian yang digunakan dalam penelitian ini adalah dengan menggunakan teknik Nonprobability Sampling, yaitu teknik pengambilan sampel yang tidak memberi peluang/kesempatan sama bagi setiap unsur atau anggota populasi untuk dipilih menjadi sampel (Sugiyono, 2015:122). Pada model pengambilan sampel dalam penelitian ini yaitu menggunakan model pengambilan purposive sampling yang dilakukan atas pertimbangan dan persetujuan antara penulis dengan guru matematika kelas VIII SMP Negeri 5 Singkawang. Jadi, sampel pada penelitian ini yaitu kelas VIII C sebagai kelas eksperimen yang berjumlah 23 orang siswa dan kelas VIII A sebagai kelas kontrol yang berjumlah 23 orang siswa. Variabel dalam penelitian ini adalah variabel bebas yaitu model pembelajaran scramble, variabel terikat yaitu kemampuan pemahaman konsep matematis siswa, respon siswa serta keterlaksanaan pembelajaran setelah diberikan pengajaran dengan menggunakan model pembelajaran scramble, dan variabel kontrol yaitu jumlah waktu pengajaran, guru yang mengajar yaitu peneliti, dan materi pembelajaran yaitu materi pola bilangan. Data yang dikumpulkan dalam penelitian ini berasal dari lembar keterlaksanaan pembelajaran yang dilakukan oleh teman sejawat untuk memperoleh data keterlaksanaan pembelajaran dengan menggunakan model pembelajaran scramble, dan tes tertulis untuk memperoleh data tentang nilai kemampuan pemahaman konsep matematis siswa yang dilaksanakan setelah proses pembelajaran, serta pemberian angket respon untuk memperoleh data tentang respon siswa setelah proses pembelajaran. Sebelum melakukan penelitian, maka dilakukan terlebih dahulu uji validitas, uji reliabilitas, tingkat kesukaran, dan daya pembeda.

Uji validitas dalam penelitian ini menggunakan validitas isi dan validitas konstruk yang dilakukan oleh dua orang dosen pendidikan matematika dan satu orang guru bidang studi matematika sebagai validator. Adapun hasil rekapitulasi perhitungan validitas konstruk dapat dilihat pada Tabel 1 berikut.

Tabel 1. Rekapitulasi Nilai Validitas Konstruk

\begin{tabular}{ccc}
\hline Butir soal & Nilai Validitas Konstruk & Interpretasi \\
\hline 1 & 0,88 & Sangat Tinggi \\
2 & 0,89 & Sangat Tinggi \\
3 & 0,87 & Sangat Tinggi \\
\hline
\end{tabular}

Maka, selanjutnya yaitu menghitung nilai uji reliabilitas soal, dalam penelitian ini dengan menggunakan rumus Koefisien Alpha atau Cronbach's Alpha. Adapun hasil rekapitulasi perhitungan nilai reliabilitas disajikan dalam Tabel 2 berikut ini.

Tabel 2. Rekapitulasi Tingkat Reliabilitas Ujicoba Soal

\begin{tabular}{cccccc}
\hline $\begin{array}{c}\text { Butir } \\
\text { Soal }\end{array}$ & $\mathbf{1}$ & $\mathbf{2}$ & $\mathbf{3}$ & Reliabilitas & $\begin{array}{c}\text { Tingkat } \\
\text { Reliabilitas }\end{array}$ \\
\hline $\begin{array}{c}\text { Jumlah } \\
\mathbf{S i}^{2}\end{array}$ & 181 & 212 & 209 & 0,84 & $\begin{array}{c}\text { Sangat } \\
\text { Tinggi }\end{array}$ \\
\hline
\end{tabular}

Tingkat kesukaran bertujuan untuk mengkaji soal-soal tes yang diujicobakan dari sisi kesulitan soal, sehingga dapat diperoleh soal-soal yang termasuk ke dalam kategori mudah, sedang, dan sulit. Adapun hasil rekapitulasi perhitungan tingkat kesukaran soal dapat disajikan pada Tabel 3 berikut ini. 
Journal of Educational Review and Research

Vol. 4 No. 1, July 2021: $44-51$

e-ISSN: 2597-9760, p-ISSN: 2597-9752

Tabel 3. Rekapitulasi Tingkat Kesukaran Ujicoba Soal

\begin{tabular}{ccc}
\hline $\begin{array}{c}\text { Butir } \\
\text { Soal }\end{array}$ & Tingkat Kesukaran & Kriteria \\
\hline 1 & 0,72 & Mudah \\
2 & 0,63 & Sedang \\
3 & 0,62 & Sedang \\
\hline
\end{tabular}

Daya pembeda yaitu kemampuan dari tes tersebut dalam memisahkan antara subjek yang pandai dengan subjek yang kurang pandai. Adapun hasil rekapitulasi daya pembeda soal dapat disajikan pada Tabel 4 berikut ini.

Tabel 4. Rekapitulasi Daya Pembeda Ujicoba Soal

\begin{tabular}{ccc}
\hline $\begin{array}{c}\text { Butir } \\
\text { Soal }\end{array}$ & Nilai Daya Pembeda & Kriteria \\
\hline 1 & 0,23 & Cukup \\
2 & 0,21 & Cukup \\
3 & 0,22 & Cukup \\
\hline
\end{tabular}

Analisis data yang dilakukan yaitu menggunakan uji normalitas, uji homogenitas dan uji-t. Setelah data berdistribusi normal, homogen dan terdapat perbedaan antara kelas eksperimen dan kelas kontrol, maka selanjutnya digunakan rumus effect size, sedangkan untuk mengetahui pengaruh respon siswa dengan membandingkan rerata skor sikap netralnya dengan rerata skor sikap siswa, dan untuk mengetahui keterlaksanaan model pembelajaran scramble pada materi pola bilangan yaitu menghitung persentase banyaknya siswa mengikuti pembelajaran.

\section{HASIL DAN PEMBAHASAN}

\section{Pengaruh Model Pembelajaran Scramble Terhadap Kemampuan Pemahaman Konsep Matematis Siswa}

Data yang disajikan dalam penelitian ini adalah data yang diperoleh dari hasil jawaban soal posttest yang diberikan kepada kelas eksperimen dan kelas kontrol. Adapun soal posttest yang diberikan berbentuk tes kemampuan pemahaman konsep matematis sebanyak 3 soal dengan indikator-indikator sebagai berikut yaitu: (1) menyatakan ulang suatu konsep; (2) mengklasifikasikan objek-objek menurut sifat-sifat tertentu sesuai dengan konsepnya; dan (3) menyajikan konsep dalam berbagai bentuk representasi matematika; dan (4) menggunakan, memanfaatkan, dan memilih prosedur atau operasi tertentu. Adapun rekapitulasi rata-rata nilai posttest kemampuan pemahaman konsep matematis siswa kelas eksperimen dan kelas kontrol ditinjau dari keseluruhan data disajikan pada Tabel 5 berikut.

Tabel 5. Rekapitulasi Nilai Rata-rata Posttest Kemampuan Pemahaman Konsep Matematis Siswa

\begin{tabular}{ccc}
\hline Keterangan & Kelas Eksperimen & Kelas Kontrol \\
\hline Rata-rata & 69,43 & 53,89 \\
Standar Deviasi & 8,86 & 5,07 \\
\hline
\end{tabular}

Dari data tersebut menunjukkan bahwa nilai rata-rata skor dari ketiga soal posttest pada kelas eksperimen adalah 69,43 pada kelas kontrol adalah 53,89. namun sebelumnya rata-rata skor posttest kelas eksperimen dan kelas kontrol dilakukan terlebih dahulu uji normalitas dan homogenitas variansi data.

Uji normalitas dilakukan dengan menggunakan uji statistik Liliefors. Adapun rekapitulasi hasil uji normalitas Liliefors data posttest untuk kelas eksperimen dan kelas kontrol, dapat dilihat pada Tabel 6 berikut ini. 
Journal of Educational Review and Research

Vol. 4 No. 1, July 2021: $44-51$

e-ISSN: 2597-9760, p-ISSN: 2597-9752

Tabel 6. Rekapitulasi Hasil Uji Normalitas Data

\begin{tabular}{cccc}
\hline Keterangan & Kelas Eksperimen & Kelas Kontrol \\
\hline $\mathbf{L}_{\text {hitung }}$ & 0,0989 & 0,0842 \\
$\mathbf{L}_{\text {tabel }}$ & & 0,1730 & \\
\hline
\end{tabular}

Pada Tabel 6 di atas, terlihat bahwa $\mathrm{L}_{\text {hitung }}$ kelas eksperimen yaitu 0,0989 dan $\mathrm{L}_{\text {hitung }}$ kelas kontrol yaitu 0,0842 dengan $\mathrm{L}_{\text {tabel }}$ 0,1730. Berdasarkan syarat atau kriteria pengujian, maka dapat disimpulkan bahwa data skor posttest pada kelas eksperimen dan kelas kontrol berdistribusi normal.

Setelah data posttest kelas eksperimen dan kelas kontrol dihitung dan diketahui berdistribusi normal, selanjutnya adalah menguji homogenitas kedua data dengan Uji Fisher. Adapun rekapitulasi hasil uji homogenitas kelas eksperimen dan kelas kontrol dapat dilihat pada Tabel 7 sebagai berikut.

Tabel 7. Rekapitulasi Hasil Uji Homogenitas Data Kelas Eksperimen dan Kelas Kontrol

\begin{tabular}{cccc}
\hline Keterangan & Kelas Eksperimen & & Kelas Kontrol \\
\hline Varians & 194,89 & & 111,65 \\
F $_{\text {hitung }}$ & & 1,75 & \\
F $_{\text {tabel }}$ & & 1,98 & \\
\hline
\end{tabular}

Berdasarkan Tabel 7 terlihat bahwa varians kelas eksperimen adalah 194,89 dan varians kelas kontrol adalah 111,65 sehingga diperoleh $F_{\text {hitung }} 1,75$ dan $F_{\text {tabel }}$ 1,98. Diketahui 1,75 $<1,98$, maka dapat disimpulkan bahwa varians data posttest kedua kelas adalah homogen.

Selanjutnya dilakukan analisis statistik uji perbedaan dua rata-rata sampel. Adapun rekapitulasi hasil perhitungan dua rata-rata siswa pada kelas eksperimen dan kelas kontrol dapat dilihat pada Tabel 8 sebagai berikut.

Tabel 8. Rekapitulasi Perhitungan Dua Rata-rata Kelas Eksperimen dan Kelas Kontrol

\begin{tabular}{ccccccc}
\hline Keterangan & $\sum X_{1}$ & $\sum X_{2}$ & $\overline{X_{1}}$ & $\overline{X_{2}}$ & $S_{1}^{2}$ & $S_{2}^{2}$ \\
\hline Skor & 1604 & 1245 & 69,74 & 54,13 & 8,86 & 5,07 \\
$\mathbf{t}_{\text {hitung }}$ & & & 7,33 & & & \\
$\mathbf{t}_{\text {tabel }}$ & & & 1,713 & & & \\
\hline
\end{tabular}

Berdasarkan pada Tabel 8 di atas, terlihat bahwa $t_{\text {hitung }}$ yaitu 7,33 dan $t_{\text {tabel }} 1,713$. Karena 7,33>1,733, maka $\mathrm{H}_{\mathrm{a}}$ diterima. Artinya terdapat perbedaan kemampuan pemahaman konsep matematis siswa pada kelas eksperimen dan kelas kontrol.

Selanjutnya untuk mengetahui seberapa besar pengaruh model pembelajaran scramble terhadap kemampuan pemahaman konsep matematis siswa digunakan rumus Effect Size. Adapun rekapitulasi hasil perhitungan dengan rumus Effect Size dapat dilihat pada Tabel 9 berikut ini.

Tabel 9. Rekapitulasi Hasil Perhitungan Effect Size Siswa Kelas Eksperimen dan Kelas Kontrol

\begin{tabular}{ccc}
\hline Keterangan & Kelas Eksperimen & Kelas Kontrol \\
\hline SD & 8,86 & 5,07 \\
Effect Size $($ ES $)$ & & $\mathbf{1 , 7 5}$ \\
Kriteria & \multicolumn{3}{c}{ Tinggi } \\
\hline
\end{tabular}

Berdasarkan perhitungan Effect Size pada Tabel 9 di atas, maka diperoleh nilai Effect Size yaitu 1,75 dengan kriteria tinggi. Hal ini dapat disimpulkan yaitu terdapat pengaruh model pembelajaran scramble terhadap kemampuan pemahaman konsep matematis siswa. 


\section{Respon Siswa Terhadap Penggunaan Model Pembelajaran Scramble}

Data respon siswa diperoleh dari hasil angket respon yang diisi oleh siswa. Angket ini berisi 20 pernyataan yang terdiri dari 17 pernyataan positif dan 3 pernyataan negatif, siswa hanya perlu memberi tanda checklist $(\sqrt{ })$ pada kolom yang tersedia sebanyak 5 buah. Keterangan untuk masingmasing kolom tersebut yaitu Sangat Setuju (SS), Setuju (S), Ragu-ragu (R), Kurang Setuju (KS), dan Tidak Setuju (TS). Berdasarkan hasil perhitungan angket respon siswa, dapat diketahui bahwa ratarata respon siswa secara keseluruhan yaitu sebesar 76,52 dengan kriteria positif. Jadi dapat disimpulkan bahwa terdapat pengaruh model pembelajaran scramble terhadap respon siswa pada materi pola bilangan.

\section{Keterlaksanaan Model Pembelajaran Scramble}

Data keterlaksanaan pembelajaran diperoleh dari hasil observasi atau pengamatan selama mengikuti pembelajaran dengan menggunakan model pembelajaran scramble dari awal pembelajaran sampai akhir pembelajaran. Adapun rekapitulasi hasil pengamatan keterlaksanaan pembelajaran siswa dapat disajikan dalam Tabel 10 berikut ini.

Tabel 10. Rekapitulasi Hasil Perhitungan Keterlaksanaan Pembelajaran

\begin{tabular}{ccc}
\hline & Pengamat I & Pengamat II \\
Jumlah Skor & 42 & 44 \\
Persentase & $84 \%$ & $88 \%$ \\
\hline Persentase Keseluruhan & \multicolumn{3}{c}{$\mathbf{8 6 , 0 0 \%}$} \\
Kriteria & \multicolumn{3}{c}{ Sangat Baik } \\
\hline
\end{tabular}

Berdasarkan hasil pengamatan keterlaksanaan pembelajaran yang dilakukan oleh kedua pengamat, maka rata-rata persentase keseluruhan hasil pengamatan keterlaksanaan pembelajaran yaitu sebesar $86 \%$ dengan kriteria sangat baik.

Faktor yang memengaruhi kemampuan kemampuan pemahaman konsep matematis siswa adalah penerapan model pembelajaran scramble dengan rangkaian kegiatan pembelajaran yang menarik, yaitu siswa dapat memahami permasalahan, merumuskan jawaban dari permasalahan, dan siswa mencari dan menemukan jawaban dengan menghubungkan pengetahuan konsep dasar siswa itu sendiri terkait dengan materi pembelajaran sehingga kemampuan pemahaman konsep matematis siswa menjadi lebih baik. Hal ini juga sejalan dengan penelitian yang dilakukan oleh Rosmaiyadi (2018:149), Hasil penelitian menunjukkan bahwa terdapat perbedaan peningkatan kemampuan pemahaman konsep matematis antara siswa yang diberikan strategi pembelajaran Group to Group exchange dengan pendekatan kontekstual dengan siswa yang diberikan model pembelajaran langsung.

Keberhasilan model pembelajaran scramble memberikan pengaruh terhadap kemampuan pemahaman konsep matematis siswa kelas VIII di SMP Negeri 5 Singkawang, sejalan dengan penelitian yang dilakukan oleh Mayasari (2016), hasil penelitian menunjukkan bahwa peningkatan kemampuan pemahaman konsep matematis siswa yang mendapatkan pembelajaran dengan teknik scramble lebih baik daripada siswa yang mendapatkan pembelajaran dengan teknik pembelajaran konvesional. Kondisi ini dikarenakan siswa terlibat langsung dalam proses belajar, siswa menyampaikan gagasan secara tertulis melalui pertanyaan dan jawaban dalam kegiatan kelompok. Melalui pembelajaran yang menekankan keterkaitan antargagasan dalam matematika, siswa tidak hanya belajar matematika, tapi mereka juga belajar tentang kegunaan matematika. Ketika siswa mampu mengaitkan antar gagasan dalam matematika, pemahaman mereka menjadi lebih mendalam dan lebih tahan lama. Hal tersebut juga sejalan dengan teori belajar bermakna dari Ausubel (dalam Dahar, 2006:94) yang menyatakan bahwa belajar bermakna merupakan suatu proses dimana setiap informasi atau pengetahuan baru dihubungkan dengan struktur pengertian atau pemahaman yang sudah dimiliki oleh siswa sebelumnya.

Dari uraian tersebut pembelajaran dengan menggunakan model pembelajaran scramble pada materi pola bilangan dikatakan dapat memberikan pengaruh terhadap kemampuan pemahaman konsep 
matematis siswa sebesar 1,75 berdasarkan perhitungan dari Effect Size dengan kategori tinggi, yang berarti bahwa hipotesis penelitian dapat diterima yaitu terdapat pengaruh model pembelajaran scramble terhadap kemampuan pemahaman konsep matematis siswa pada materi pola bilangan.

Adapun faktor yang memengaruhi respon siswa adalah penerapan model pembelajaran scramble yang dirancang untuk mengajak siswa belajar dengan menggunakan media kartu soal dan jawaban, siswa dengan asik mencari jawaban dari beberapa kartu soal, kemudian dicocokkan ke kartu jawaban yang tersedia. Siswa dengan penuh percaya diri menyampaikan pendapatnya sendiri tanpa ada rasa canggung untuk berbicara di depan kelas, siswa menjadi bersemangat untuk menjadi yang terbaik diantara teman-teman sekelasnya sehingga terjadinya persaingan secara sehat antara siswa. Hal tersebut sejalan dengan penelitian yang dilakukan oleh Ekawati dkk (2013), hasil dari penelitian menujukkan bahwa penggunaan model pembelajaran scramble dapat memberikan respon siswa dalam memecahkan masalah matematika pada materi bilangan bulat. Dari uraian tersebut, maka dapat disimpulkan bahwa terdapat pengaruh model pembelajaran scramble terhadap respon siswa pada materi pola bilangan.

Berdasarkan hasil pengamatan keterlaksanaan pembelajaran yang dilakukan oleh kedua pengamat, maka rata-rata persentase keseluruhan hasil pengamatan keterlaksanaan pembelajaran yaitu sebesar $86 \%$. Berdasarkan kriteria keterlaksanaan pembelajaran oleh guru termasuk ke dalam kriteria sangat baik. Ini berarti sudah menunjukkan adanya keterlaksanaan pembelajaran dengan menggunakan model pembelajaran scramble. Hal tersebut juga sejalan dengan penelitian yang dilakukan oleh Susanto (2015), hasil penelitian menunjukkan bahwa aktivitas siswa terhadap pembelajaran matematika meningkat berada pada kategori aktif yaitu dengan rata-rata total sebesar $87,5 \%$. Dari uraian tersebut dapat disimpulkan bahwa terdapat pengaruh model pembelajaran scramble terhadap keterlaksanaan pembelajaran pada materi pola bilangan.

\section{KESIMPULAN DAN SARAN}

Dari hasil penelitian yang dilakukan, secara umum dapat disimpulkan bahwa terdapat pengaruh model pembelajaran scramble terhadap kemampuan pemahaman konsep matematis siswa. Secara khusus dapat disimpulkan beberapa hal sebagai berikut. (1) Terdapat pengaruh penggunaan model pembelajaran scramble terhadap kemampuan pemahaman konsep matematis siswa pada materi pola bilangan kelas VIII SMP Negeri 5 Singkawang dengan nilai Effect Size (ES) yaitu 1,75; (2) Respon siswa positif terhadap model pembelajaran scramble pada materi pola bilangan dengan rata-rata skor mencapai 76,52; (3) Penggunaan model pembelajaran scramble pada materi pola bilangan terlaksana dengan kriteria sangat baik yaitu mencapai persentase sebesar $86,00 \%$.

Saran yang dapat disampaikan diantaranya yaitu model pembelajaran scramble sebagai satu diantara alternatif model pembelajaran yang menarik untuk dilaksanakan di sekolah, sebab model pembelajaran scramble dapat memberikan pengaruh terhadap kemampuan pemahaman konsep matematis siswa. Model pembelajaran scramble diterapkan pada proses belajar mengajar pada materi lainnya juga, selain materi pola bilangan. Penelitian mengenai penggunaan model pembelajaran scramble dalam pembelajaran matematika hendaknya lebih dikembangkan dengan penggunaan model pembelajaran jenis lain oleh peneliti-peneliti selanjutnya.

\section{DAFTAR PUSTAKA}

Dahar, Ratna. 2006. Teori-Teori Belajar \& Pembelajaran. Jakarta: Erlangga.

Ekawati, R., Junaedi, I. and Nugroho, S.E., 2013. Studi respon siswa dalam menyelesaikan soal pemecahan masalah matematika berdasarkan taksonomi SOLO. Unnes Journal of Mathematics Education Research, 2(2). 
Fitriyani. 2017. Pengaruh Metode Resitasi Terhadap Kemampuan Pemahaman Konsep Matematika Siswa. Jurnal. FTMIPA, Universitas Indraprasta PGRI Jakarta.

Hadi, Sutarto. 2015. Pemahaman Konsep Matematika Siswa Smp Melalui Penerapan Model Pembelajaran Kooperatif Tipe Memeriksa Berpasangan (Pair Checks). Jurnal. Universitas Lambung Mangkurat Banjarmasin.

Isrotun, Umi. 2014. Peningkatan Pemahaman Konsep Matematika Melalui Penerapan Pembelajaran Realistik. Jurnal. Universitas Muhammadiyah Surakarta.

Mayasari, Riya. 2016. Pengaruh Metode Scramble dalam Pembelajaran Matematika terhadap Kemampuan Pemahaman Matematis Siswa Kelas XI SMK Negeri 2 Kediri. Jurnal. Universitas Nusantara PGRI Kediri.

Rabeka. 2018. Pengaruh Model Pembelajaran Scramble Berbantuan Flashcard Terhadap Hasil Belajar Materi Klasifikasi Makhluk Hidup. Jurnal. Universitas Tanjungpura Pontianak.

Rosmaiyadi, R., Mariyam, M. and Juliyanti, J., 2018. Pemahaman Konsep Matematis Siswa Dengan Strategi Pembelajaran Group To Gruop Exchange Berpendekatan Kontekstual. JPPM (Jurnal Penelitian dan Pembelajaran Matematika), 11(1).

Sari, Apriliana. 2014. Pengaruh Model Pembelajaran Kooperatif Tipe Scramble Pada Materi Statistik Terhadap Hasil Belajar Siswa Kelas IX SMP Ma'arif 1 Ponorogo Tahun Pelajaran 2013/2014. Jurnal. Universitas Muhammadiyah Ponorogo.

Sugiyono. 2015. Metode Penelitian Pendidikan. Bandung: Alfabeta.

Susanto, H.A. and Murwaningsih, U., 2015. Improving students' activity in mathematics communication trough metacognitive learning approach based on lesson study. International Journal of Education and Research, 3(2), pp.169-180.

Utami, C. and Anitra, R., 2019. Kemampuan Pemahaman Konsep Matematis Mahasiswa Ditinjau Dari Kemampuan Awal Pada Mata Kuliah Matematika SD. Primary: Jurnal Keilmuan dan Kependidikan Dasar, 11(02), pp.103-110. 